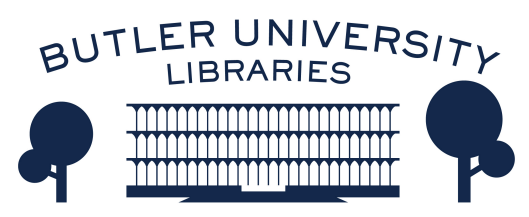

Journal of Hindu-Christian Studies

Volume 10

Article 16

January 1997

\title{
Book Review: "Revelation, History, and the Dialogue of Religions: A Study of Bhartrhari and Bonaventure"
}

Francis X. Clooney

Follow this and additional works at: https://digitalcommons.butler.edu/jhcs

Part of the Religion Commons

\section{Recommended Citation}

Clooney, Francis X. (1997) "Book Review: "Revelation, History, and the Dialogue of Religions: A Study of Bhartrhari and Bonaventure"," Journal of Hindu-Christian Studies: Vol. 10, Article 16.

Available at: https://doi.org/10.7825/2164-6279.1162

The Journal of Hindu-Christian Studies is a publication of the Society for Hindu-Christian Studies. The digital version is made available by Digital Commons @ Butler University. For questions about the Journal or the Society, please contact cbauman@butler.edu. For more information about Digital Commons @ Butler University, please contact digitalscholarship@butler.edu. 
context of Neo-Vedānta decides the content of the gospel in Jesus" (p.43). This is, in my view, a questionable approach to the context of Indian thought in that it perpetuates the myth begun in the early years of Indology that Advaita and modern reinterpretations thereof define all that is important in Indian and Hindu thought. Certainly recent scholarship on HinduChristian dialogue would challenge such privileging of Advaita and Neo-Vedānta in the context of Hindu thought. The author's description of the Indian ethos of pluralism must also be subjected to challenge. To argue that historically for the orthodox
Hindu any one dharma was not considered unique or superior seems to ignore the fundamental distinction between moksa dharma and other dharmas in classical Hindu thought.

Notwithstanding the issues raised above, the volume is a useful one for anyone interested in summaries of Neo-Vedāntic thinking on Christianity and the convergence or lack of convergence of this thinking with Indian Christian christological constructions.

Ronald Neufeldt University of Calgary

\section{Revelation, History, and the Dialogue of Religions: A Study of Bhartrhari and Bonaventure. David Carpenter. Maryknoll: Orbis, 1995, $\mathrm{xi}+20 \dot{8} \mathrm{pp}$.}

IN THIS BOOK David Carpenter undertakes a comparative study of the Indian grammarian and philosopher of language Bhartrhari (450-500 CE) and the Christian theologian Bonaventure (1221-1274), with a particular focus on revelation as exemplified in their respective scriptures, the Veda and the Gospel. Carpenter describes this project as an exercise in the history of religions and not in theology because, while he respects the importance of revelation and its truth for believers, he does not begin with any specific presupposition about how the truth of Veda or Gospel should impact the scholar's work. Rather, he is interested in determining what is meant by "revelation" and how it functions in these different religious systems. As a historian of religion, he wants to thematize revelation as an object of historical-critical scrutiny, examining "the diversity of disclosive or revelatory phenomena and the forms of their mediation" (p.5).

Carpenter pursues his inquiry through balanced and detailed considerations of Bhartrhari and Bonaventure. Bhartrhari is considered in the first part of the book, Bonaventure in the second, while the third part lays out points for comparison similarities and differences - and evaluates these points. Carpenter does a masterful job in chapters 2 and 3 in presenting Bhartrhari's difficult writings - grammatical and metaphysical statements are deeply intertwined - in a clear and accessible way. He helps us to understand Bhartrhari's deep consideration of Sanskrit, an analysis rooted in the language's grammatical details and in its larger role as reflective of a first Word original to the world, as the self-expression of the primal verbal reality, Śabda-Brahman. By comparison, the usually formidable Bonaventure seems rather accessible; chapters on his context (ch. 4), metaphysics of revelation (ch. 5), the history of revelation (ch. 6), and the reception of the language of revelation (ch.7) show us how rich and imaginative a thinker Bonaventure was, as a theoretician, practitioner, and preacher of the Christian faith, one who admirably intertwined the historical specificity of Jesus Christ with a larger 
understanding of the world. Carpenter's first-rate research on each figure could well have served as the basis for two separate books.

This is a difficult historical comparison, because we actually know so little about Bhartṛhari. His Vākyapadìya is a masterpiece which combines grammatical analysis with reflection on the metaphysical and cosmological foundations of human and sacred language, but it gives us no direct information about his life or experience. By contract, we know so much more about Bonaventure, the theologian, preacher, and Superior General of the Franciscan religious order. As a committed historian of religion, Carpenter has to draw a great deal on a broad sense of classical Indian history, and in particular on his understanding of the brahmanical worldview in its post-Buddhist phase, in order to bring a sense of Bhartrhari's context into dialogue with all that we know about Bonaventure's life and times. So too, although Carpenter's decision to use Bhartrhari as the counterpart to Bonaventure is quite appropriate given his focus on the language of revelation, at least some of the same ground might have been covered more smoothly and simply through a study of a thinker from a theistic brahmanical tradition - e.g., Udayana from the Nyāya school, or Rāmānuja from the Vedānta school.

In any case, the final two chapters pull the comparison together in a very interesting and valuable fashion. Chapter 8 highlights key differences in their views: e.g., Bhartrhari is thinking of a primordial revealing of Dharma that is constitutive of the world, while Bonaventure envisions the self-communication of a personal God in history and through specific historical voices and persons. Bonaventure sees the Gospel as addressed to all people, while Bhartrhari expects a limited audience of those prepared for this subtle and complex communication. Carpenter honestly recognizes differences and challenges us to take them seriously, but he also enables us to assess and appreciate them more fruitfully. In chapter 9, Carpenter identifies important similarities that are not diminished by the differences. For both Bhartrhari and Bonaventure, he observes, the language of revelation is practical, originating in spiritual experience, and re-enacted in proper transmission and proper reception, all of which lead to the transformation of the individuals. Revelation is in process, (for us at least) articulated over time; Reality, whether "personal" or not, is self-expressive in acts of disclosure which are at the core of what is meant by "revelation". To explain how truth is disclosive, Carpenter points us to the writings of the German philosopher HansGeorg Gadamer, for whom truth is not a fixed content stated definitively, ruling out competing claims, but instead a disclosure of the world "that roots both the subjective and objective moments in the experience of truth in the self-manifestation of reality itself" (p.194).

Revelation, History, and the Dialogue of Religions is a complete, erudite, and balanced comparative study, one of the best available today. It is an exemplary contribution to Hindu-Christian studies in particular because Carpenter has mastered difficult material from both traditions, approaches them with great sensitivity, and ventures prudent conclusions about how the comparison helps us today. Ultimately, he has hopes that reach beyond the academic realm; he seeks "to defamiliarize the concept of revelation itself, in its unquestioned immediacy, and contribute to the attitude of radical openness and questioning that I believe is called for by the present situation" (p.13). Careful comparative study of our core religious claims will enable us to think constructively about revelation in a comparative context so that, in the long run, the very truth claims which often seem to divide believers of different faiths may become a resource for their mutual respect. In its specific form, this is a study about difficult classical texts and pre-modern debates; but if contemporary Christians and Hindus read 
the book and discuss it together, it should make a very important contribution to the conversation occurring between traditions today.
Francis X. Clooney, S.J.

Boston College

\section{The Bible Trembled: The Hindu-Christian Controversies of Nineteenth Century Ceylon. R. F. Young and S. Jebunesan. (Vol. XXII, Publications of the De Nobili Research Library). Vienna: Institute of Indology, University of Vienna, 1995.}

"THE BIBLE TREMBLED at the fierce battle engaged with Muttukamārak Kavirāyar (1780-1851); the Bible fell down and lay unconscious when attacked by Nāvalvar; and now it lies dead, smitten by Tāmōtaram Pillai (1832-1901)."

Capāpati Nāvalvar's poem reflects the intent and spirit of Hindu revivalism and anti-Christian sentiment in nineteenthcentury Jaffna, Ceylon (Śrī Lanka). His verse also provided an attractive title for this excellent book by $R$. F. Young and S. Jebunesan on Hindu-Christian controversies of the period. The authors have mapped the origins and development of Hindu revival movements with great skill considering the diversity of elements involved in such a study. The approach is basically historical but the events are presented in the context of socio-religious movements in which the Hindu communities are seen to be concerned with the revitalization of their society "by reference to a past, remembered nostalgically, when religion was thought to be pure and society conducted itself accordingly". The bibliography for this study is encyclopedic. It is used in such a way as to let the protagonists in the controversies speak for themselves in language which ranges from egregious calumny to sublime philosophical discourse.

The engagement of Christians and Hindus was not a simple matter of contention between entrenched, well-defined orthodoxies, nor was it a case of repetitive argument about points of theological or doctrinal difference and disagreement. Issues changed over the period. Hindu astrology contended with true astronomy; historical Bible contended with mythic Purana; the moral character of deities was debated; the use of idols was condemned and defended. In addition, Tamil Śaivites were having their own struggles within the larger Hindu community. The concern of non-brahmin castes about the Dravidian rather than the Sanskrit origins of their culture, language, and religion resulted in growing animosity toward the Sanskritized Brahmins, their ritual patterns and scriptural bases. Christian missionaries felt they had an ally with this kind of reform but learned to their chagrin that it was a powerful force in the strengthening of Hindu self-esteem.

In their mapping the authors delineate the differences that characterized religious reforms in various areas. Those on which they concentrate were in the north of Śri Lanka around Jaffna in the Saivite Hindu communities. There were movements in the south among the Buddhist Sinhalese but they were quite different in origin and manifestation. Similarly the Tamils of mainland India were engaged in reform movements which have similarities but significant differences. Elaborating the details of these variations has given a sense of time and location as well as introduced us to the personalities involved.

The coming of protestant Christianity to Jaffna had profound results. These results were not those anticipated by the 